Acta Theriologica 38 (4): 453 - 456, 1993.

PL ISSN $0001-7051$

\title{
Burrow structure of two gerbil species of Thar desert, India
}

\author{
Surendra P. GOYAL ${ }^{1}$ and Pulak K. GHOSH
}

Goyal S. P. and Ghosh P. K. 1993. Burrow structure of two gerbil species of Thar desert, India. Acta theriol. 38: $453-456$.

We examined the seasonal changes in burrow structure of Indian gerbil Tatera indica (Hradwicke, 1807) and Indian desert gerbil Meriones hurrianae Jerdon, 1867 by excavating their natural burrows in the Thar desert of India. Burrow system of $T$. indica is of a simple ' $\mathrm{Y}$ ' shaped type with one or two surface openings whereas $M$. hurrianae tend to congregate in complicated and extensive burrow systems with numerous surface openings. T. indica showed a seasonal shift in maximum burrow depth, i.e. from $35 \mathrm{~cm}$ in winter to $45-50 \mathrm{~cm}$ in summer. M. hurrianae did not exhibit any seasonal change in burrow depth.

Central Arid Zone Research Institute, Jodhpur 342003, Rajasthan, India

Key words: Tatera indica, Meriones hurrianae, burrow structure, Thar desert, India

\section{Introduction}

Rodents constitute one of the largest mammalian groups in the Thar desert of north-western India, both in terms of total number and 50 species (Prakash 1975). Of the 17 species and sub-species of rodents belonging to the families Sciuridae and Muridae reported from this desert, the nocturnal Indian gerbil Tatera indica (Hardwicke, 1807) and the crepuscular Indian desert gerbil Meriones hurrianae Jerdon, 1867 are the two most common species. They avoid the problem of thermoregulation during day time by burrowing habit. Studies on burrow structures of rodents (Kennerly 1964, Graaf and Nel 1965, Nel 1967, Kenagy and Smith 1973, Naumov and Lobachev 1975, Prakash 1975) have failed to document whether the burrow structure changes in response to temporal use of surface and season.

This study aims to describe the seasonal changes in burrow structure of two sympatric Indian desert gerbil species which differ in temporal use of surface.

\section{Methods}

We examined the burrow structure of the two species by digging out the natural burrows in their most preferred sandy habitat around Jodhpur $\left(26^{\circ} 18^{\prime} \mathrm{N} ; 73^{\circ} 01^{\prime} \mathrm{E}\right)$ during summer and winter. Frequency occurrence of burrow depths measured from surface were correlated with the data on soil temperature profiles recorded within two $\mathrm{km}$ of the study area by Climatological Laboratory of Central Arid Zone Research Institute, Jodhpur. A total of fifty and fifty eight burrows were examined

\footnotetext{
${ }^{1}$ Present address: Wildlife Institute of India, P. O. Box 18, Dehra Dun 248001, India
} 


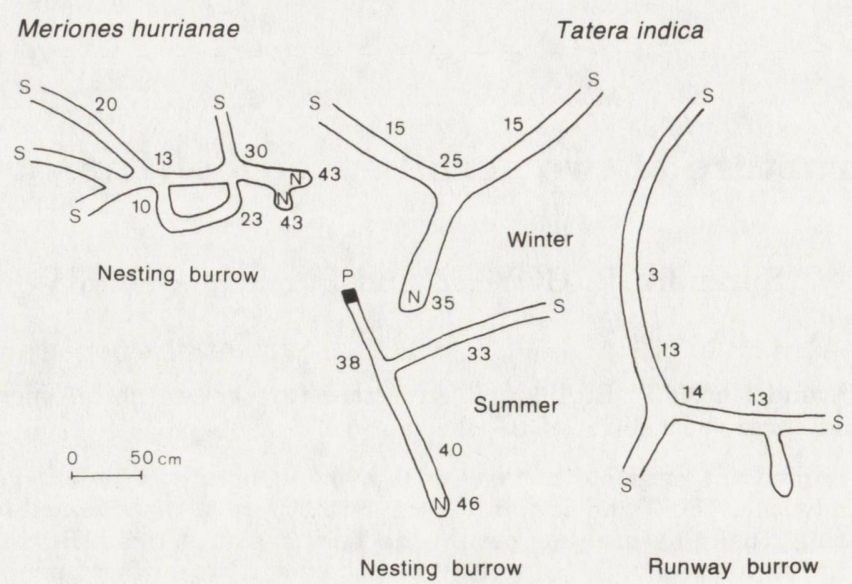

Fig. 1. Examples of burrow structure of $M$. hurrianae and $T$. indica. Figures indicate burrow depth $(\mathrm{cm})$ at specific places. $\mathrm{S}$ - surface opening, $\mathrm{N}$ - nesting place, $\mathrm{P}$ - plugged emergency exit.

for Meriones hurrianae and Tatera indica respectively during both the seasons. Any food material found in the nest of the excavated burrows was recorded.

\section{Results and discussion}

Our findings suggest that $M$. hurrianae tend to congregate in colonies and inhabit complicated and extensive burrow systems. This is in confirmation of the earlier work of Prakash (1975). One of the simplest burrow systems of this gerbil having four surface openings has been shown in Fig. 1. As many as thirty openings may be found in more complex burrow systems. Burrow pattern and maximum depth of 35 to $45 \mathrm{~cm}$ for most of the burrows remained consistent during summer and winter. The burrow systems are interlaced in such a way that it facilitates the quick retreat of species inside the burrow to shed the body heat accrued while foraging on the surface during day time.

The summer and winter burrows of $T$. indica are of a very simple type (Y-shaped), having one blind branch for nesting purposes. The winter burrows of $T$. indica with a mean maximum depth of $35 \mathrm{~cm}$ have two surface openings (Fig. 1). The summer burrows usually have one surface opening and one emergency opening which is usually kept plugged by soil particles from the inside. The maximum depth of summer burrows ranges between 45 and $50 \mathrm{~cm}$. Some shallow burrow systems of $T$. indica have been observed (Fig. 1). The maximum depth of such burrow systems is around $25 \mathrm{~cm}$ and these may be called 'temporary burrows'. During summer, rodent predators like snakes are more active and the emergency and temporary burrows would then seem to serve the purpose of providing escape routes for the rodents. The temporary burrows usually have more than two surface openings. In several burrow excavations, only a single $T$. indica was found. This suggests that it leads a solitary life. 

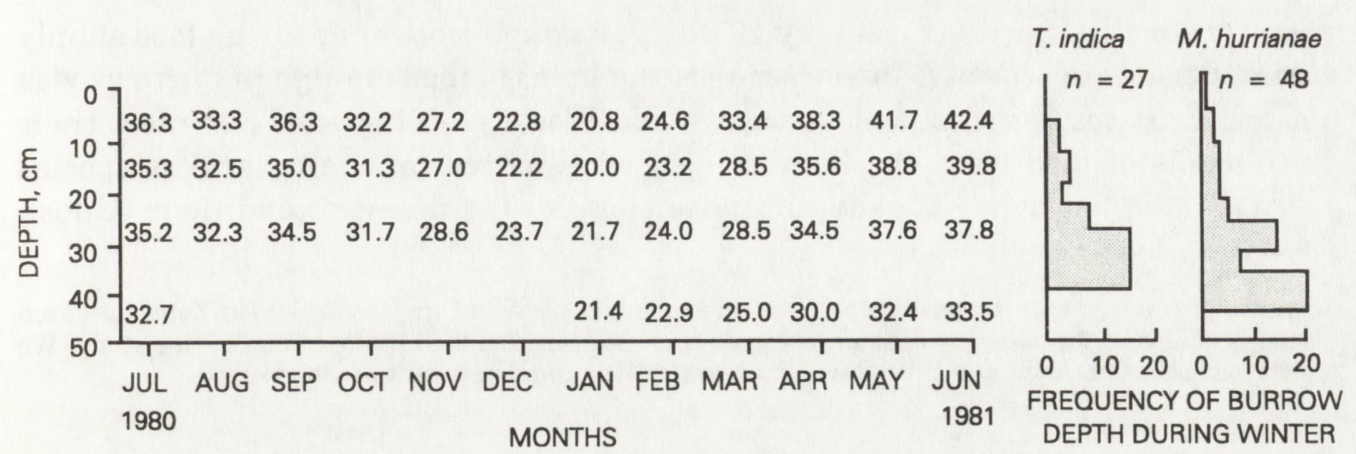

Fig. 2. Soil temperature profiles and frequency of occurrence of $T$. indica and $M$. hurrianae winter burrows of different depths. Values are temperature in ${ }^{\circ} \mathrm{C} . n$-number of burrow excavated.

The frequency distributions of maximum winter burrow depths for $T$. indica and $M$. hurrianae are shown in relation to mean soil temperatures at various depths in Fig. 2. It appears that the soil temperature between $21^{\circ} \mathrm{C}$ and $37^{\circ} \mathrm{C}$ at maximum depth of summer and winter burrows provides an ideal micro-environment to both the gerbil species. Observed seasonal changes in burrow depths of $T$. indica could indicate, that it avoid high soil temperature of about $37^{\circ} \mathrm{C}$ at a depth of $30 \mathrm{~cm}$ during summer, as species is less heat tolerant than $M$. hurrianae (Goyal 1982). It would mean that gerbils experience comparatively lesser fluctuations in ambient temperature inside the burrows than outside. Observed burrow depths and those recorded for other rodent species (Table 1) reveal that most of the burrowing species seem to have a reasonably favourable micro-environment inside the burrow at depths of $30-70 \mathrm{~cm}$ below the surface.

Burrows are used to store food by several gerbil species of Mongolia, Central Asia and ex-USSR, e.g. Meriones persicus, M. libycus, M. meridianus, Rhombomys opinus (Naumov and Lobachev 1975), and by certain New World desert hetero-

Table 1. Burrow depth of various rodent species.

\begin{tabular}{lll}
\hline Species & $\begin{array}{c}\text { Burrow depth } \\
(\mathrm{cm})\end{array}$ & \multicolumn{1}{c}{ Reference } \\
\hline Dipodomys merriami & 60 & Schmidt-Nielsen and Schmidt-Nielsen 1951 \\
D. merriami & $20-30$ & Kenagy and Smith 1973 \\
D. microps & $20-30$ & Kenagy and Smith 1973 \\
Geomys bursarius & 65 & Kennerley 1964 \\
Parotomys brantsi & 30 & Graaf and Nel 1965 \\
Desmodilus auricularis & $30-60$ & Nel 1967 \\
Neotoma albigula & $20-30$ & Kenagy and Smith 1973 \\
Perognathus longimembris & $20-30$ & Kenagy and Smith 1973 \\
Desert gerbils and jerboas of ex-USSR & $30-70$ & Naumov and Lobachev 1975 \\
Meriones hurrianae & 45 & present study \\
Tatera indica & $35-50$ & present study \\
\hline
\end{tabular}


myids of North America (Eisenberg 1975) as an adaptation for ensuring food supply during periods of scarcity. In our studies, the habit of food storage in burrows was not found. It could mean that these two Old World gerbil species can meet their daily needs of food from the fluctuating food resources of the desert, as species are well adapted behaviourally and physiologically to desertic conditions (Ghosh 1975, Goyal 1982).

Acknowledgements: Our sincere thanks are due to the Director, of the Central Arid Zone Research Institute, Jodhpur for his encouragement and enthusiastic support during the course of this study. We are thankful to Drs Asha and Shri Ravi Challem for their comments on the manuscript.

\section{References}

Eisenberg J. F. 1975. The behavior patterns of desert rodents. [In: Rodents in desert environments. I. Prakash and P. K. Ghosh, eds]. Dr W. Junk, The Hague: $189-224$.

Ghosh P. K. 1975. Thermoregulation and water economy in Indian desert rodents. [In: Rodents in desert environments. I. Prakash and P. K. Ghosh, eds]. Dr W. Junk, The Hague: $397-412$.

Goyal S. P. 1982. Ecological energetics of two desert gerbils of Rajasthan, India. Ph. D. thesis, Univ. of Jodhpur, Jodhpur: $1-320$.

Graaf G. D. and Nel J. A. J. 1965. On the tunnel system of Brant's karoo rat, Parotomys brantsi in the Kalahari Gemsbok National Park. Koedoe 9: 136 - 139.

Kenagy G. J. and Smith C. B. 1973. Radioisotopic measurement of depth and determination of temperatures in burrows of heteromyid rodents. [In: Proceedings of the Third National Symposium on Radioecology. D. J. Nelson, ed]. Nat. Tech. Inf. Serv., Springfield, VA.: $265-273$.

Kennerly T. E., Jr 1964. Microenvironmental conditions of the pocket gopher burrow. Texas J. Sci. 16: $395-441$.

Naumov N. P. and Lobachev V. S. 1975. Ecology of desert rodents of the USSR. [In: Rodents in desert environments. I. Prakash and P. K. Ghosh, eds]. Dr W. Junk, The Hague: $465-598$.

Nel J. A. J. 1967. Burrow systems of Desmodillus auricularis in the Kalahari Gemsbok National Park. Koedoe 10: $118-121$.

Prakash I. 1975. The population ecology of the rodents of the Rajasthan desert, India. [In : Rodents in desert environments. I. Prakash and P. K. Ghosh, eds]. Dr W. Junk, The Hague: $75-116$.

Schmidt-Nielsen B. and Schmidt-Nielsen K. 1951. A complete account of the water metabolism in kangaroo rats and an experimental verification. J. Cell. Comp. Physiol. 38: 165 - 182.

Received 4 March 1993, accepted 21 May 1993. 